\title{
Mechanical Characterization of Glass Fiber Aluminium Reinforced Riveted Joints
}

Karpagam Institute of Technology

India

\section{Hemanathan}

Student

Karpagam Institute of Technology India

\section{K. M. Kiran Babu}

Assistant-Professor Karpagam Institute of Technology Faculty of Mechanical Engineering

India

\section{S. Sendhilkumar}

Associate-Professor Karpagam Institute of Technology Faculty of Mechanical Engineering
The airframe of any flying vehicle comprises structural members such as stringers and stiffeners made of sheet metal members, joined by riveted lap joints. Although different joining techniques exist, the rivet type of fastening still stands efficient. Numerous such rivets are required to join the skin completely. The mechanical loading due to the pressurization and depressurization of the fuselage, which occurs once in every flight and the air loads during the cruising flight causes the concentrated stress at the rivet joints which results in the failure of joints. The main objective of this research paper is to improve the strength of the riveted joints using Fiber Metal Laminate (FML) as the reinforcing material between the riveted joints. The tensile testing of the specimens with and without reinforcement are carried out and from the results it is concluded that due to the presence of reinforcement between the riveted joints the overall mechanical strength of the riveted joints is improved.

Keywords: Riveted Joints, Fiber Metal Laminate (FML), GLARE Reinforcemen, Tensile Testing, Damage Tolerant Design

\section{INTRODUCTION}

The Joint is combining two or more components for an application. Riveting is a method of joining two components in real world using the friction between them. Present-day, the rivet joints are most commonly used in automotive sector due to the efficient clam-up, less weight and resistance to corrosion. The rivet in the rivet joint fills the hole completely arresting the relative motion between the plates. Riveting is a process of joining two or more plates with the help of a rivet. A good amount of mechanical force is to be provided to make the strong and leak proof joint. [1], [2]
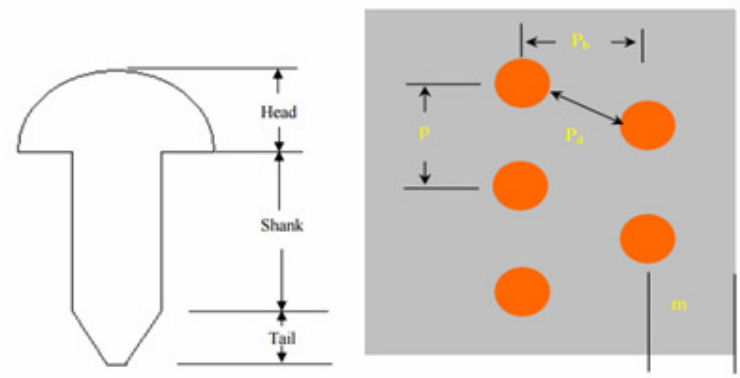

Figure 1. Important Design Parameters of the Riveted Joint

Few parameters, which are required to specify arrangement of rivets in a riveted joint, are as follows:

- Pitch (p) is the distance between two centers of the consecutive rivets in a single row.

- Back Pitch $\left(\mathrm{p}_{\mathrm{b}}\right)$ is the shortest distance between

Received: August 2015, Accepted: February 2016

Correspondence to: Mr. K M Kiran Babu

Faculty of Mechanical Engineering,

Karpagam Institute of Technology, Coimbatore, India.

E-mail: kiranbabu.aerospec@gmail.com

doi:10.5937/fmet1701089P

(c) Faculty of Mechanical Engineering, Belgrade. All rights reserved two successive rows in a multiple riveted joint.

- Diagonal pitch $\left(\mathrm{p}_{\mathrm{d}}\right)$ is the distance between the centers of rivets in adjacent rows of zigzag riveted joint.

- Margin ( $\mathrm{m})$ is the distance between the centers of the rivet hole to the nearest edge of the plate.

The main purpose of the riveted joints is to hold the two or more components together by using the friction between the joints. These kinds of joints find extensive applications in the automotive sector. The main focus in the design of the riveted joints is such that they have very good mechanical strength and durability to the wide range of loads applied. The present trend in the automotive industry is the application of Fiber Metal Laminate (FML). Fibre Metal Laminates (FML) is a kind of hybrid materials and it can be fabricated from an alternating laminate of thin metal sheets and thin composite layers. [3]

Glass Laminate Aluminum Reinforced Epoxy (GLARE) composite one of the known member of the Fiber Metal Laminate Family. GLARE is made from Aluminum layers in the range of $0.3-0.5 \mathrm{~mm}$ thick, and glass fiber reinforced composite layers in the range of $0.25-0.5 \mathrm{~mm}$ thick. One of the wide usages of GLARE composite is in the aircraft applications. FML (Glare) material with the combination of Aluminum wire mesh and Glass fiber provide very good bonding and this reduces the delamination effect. [4] In this research paper the mechanical strength of aluminum blind rivet pop with the Al8081 and Al8081 reinforced with GLARE composite is investigated.

\section{LITERATURE REVIEW}

R. O. Ritchie explains the susceptibility of ductile and brittle materials subjected to varying loads due to the usage of the riveted joints. It is summarized that the 
mechanical properties of a riveted joint can be improved by composite sandwiching between the aluminum plates. Because the glass glare composite is made up of glass fiber, aluminum mesh and epoxy. Epoxy is a brittle material with high strain absorbing property. Composite provide more fatigue life and improved strength to weight ratio which is necessary for aircraft applications nowadays. [5] Kesavamurthy Y C et. al. explains the tensile properties of different composites materials, using these results the strain energy absorbed can be calculated. These values are used for comparing of normal aluminum riveted joints with composite sandwiched aluminum riveted joints. [6] A. Skorupa and M. Skorupa have experimentally investigated the crack path and fatigue behavior of riveted lap joints in aircraft fuselage. Effects of variables related to design and production of riveted lap joints representative of longitudinal sheet connections. The nature of cracks on a riveted plate is well explained through this document. [7] K. Madhan Muthu Ganesh explains the basics of damage tolerant design and investigated the fatigue life of aluminum plates theoretically and numerically. [8] Arumulla. Suresh and Tippa Bhimasankara Rao elaborates the rivets as permanent fasteners and the Joints are classified into two categories such as, nonpermanent and permanent joints. Indian standard has provided a common size for each rivet head generally less than $12 \mathrm{~mm}$ up to $48 \mathrm{~mm}$. It also explains about rivet techniques and rivet materials. The rivet material should have tensile strength more than $350 \mathrm{~N} / \mathrm{mm} 2$ and the elongation should be less than 20\%. [2] From the detailed literature review on the riveted joints, it can be concluded that the maximum failure of the riveted joints occurs due to the crack initiation and propagation through the jointed plates. According to the Griffith Criterion the important parameter which is responsible for the crack propagation is the strain energy generated in the material due to the applied load. This research paper aims in improving the strength of the riveted joints by absorbing the strain energy using Fiber Metal Laminate (FML) as the reinforcing material between the riveted joints.

\section{RIVETED JOINT SPECIMEN PREPARATION}

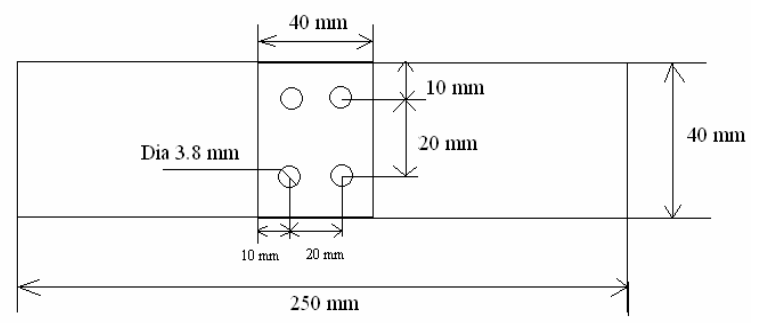

Figure 2. Riveted Lap Joint specimen

The above Figure 2, shows the dimensions of the riveted joint specimen used for the testing, the above design is based of the theoretical calculations with the sheet thickness of $1 \mathrm{~mm}$. In this section the clear description of the method followed to make the test specimens as explained. After the riveted joint calculations have been done Al8081 sheet with $1 \mathrm{~mm}$ thickness is cut by using shear cutter for given dimensions. The dimensions of the sheet are calculated. The aluminium sheets are made to cut using the shear cutter as shown below in the Figure 3.

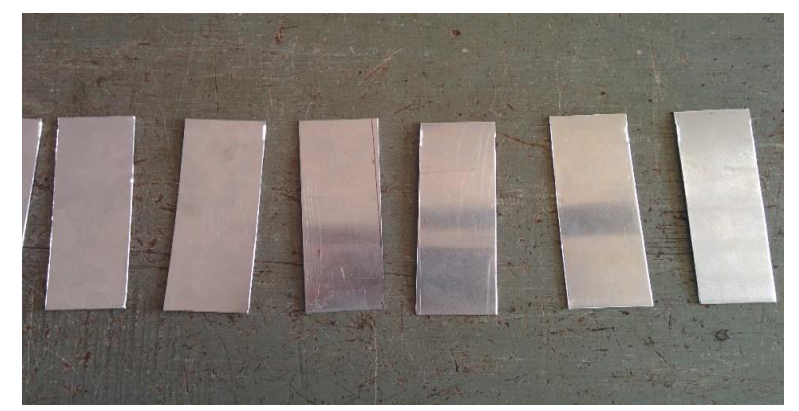

Figure 3. Aluminum plates cut using the shear cutter

The cut aluminium plates are drilled at the accurate position and the riveted joint specimens for the tensile testing are prepared. Figure 4 shows the specimen prepared for the tensile testing without and reinforcement.

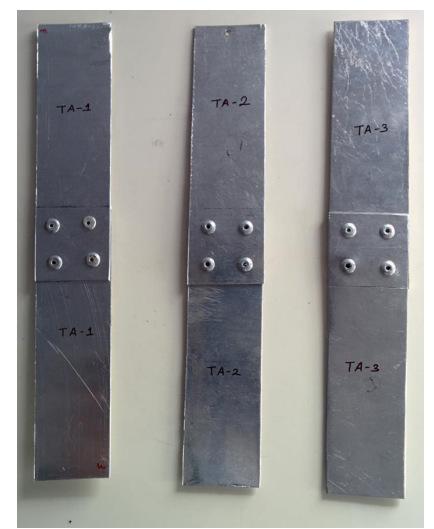

Figure 4. Riveted specimens for tensile testing

Then the fiber metal laminate GLARE composite is prepared using the compression moulding with two layers of glass fibers first layer at $0^{\circ}$ orientation and the second layer is at $90^{\circ}$ orientation and the aluminium wire mesh is used instead of the aluminium plate to reduce the delamination effect. The mould is allowed to cure for 48 hours under pressure to get better bonding between the fibers and epoxy matrix.
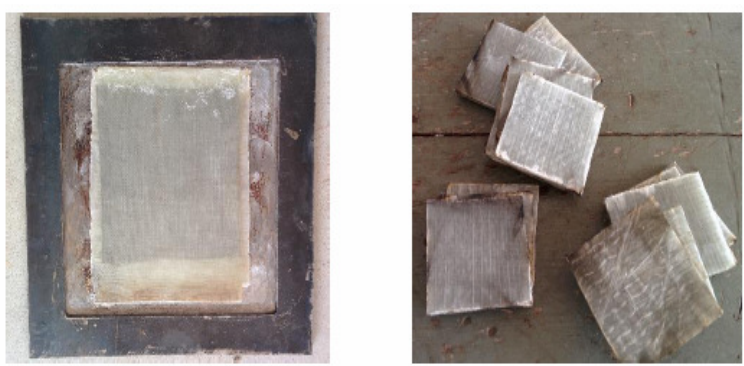

Figure 5. GLARE Composite Preparation

The Figure 5, shows the mould used for composite preparation and the pieces of GLARE composite cut with $40 \times 40 \mathrm{~mm}$ dimensions and these are placed as the reinforcement between the aluminium plates. The prepared GLARE composite is placed as the reinforcement material between the aluminium plates and the riveted joint is mage using rivet gun. The Figure 6, shows the schematic representation of the GLARE reinforced riveted joints. 


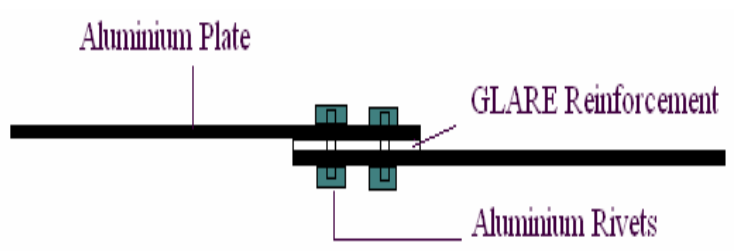

Figure 6. GLARE Reinforced Riveted Joint

\section{RESULTS AND DISCUSSION}
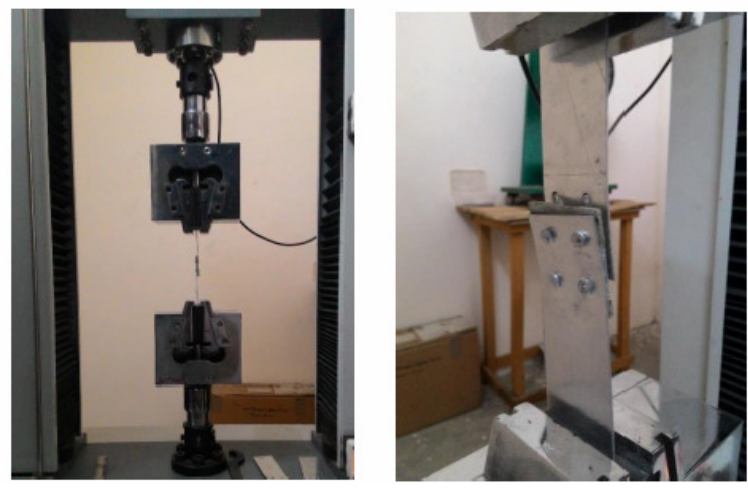

Figure 6. Testing in universal Testing Machine

To study the effect of the reinforcement in the riveted joints 6 specimens were prepared ( 3 without reinforcement and 3 with reinforcement) these specimens were subjected to the tensile testing in Universal Testing Machine (UTM), Figure 6 shows the specimen loaded in the UTM. The results obtained from the testing are discussed in this section.

Table 1. Ultimate Load Results

\begin{tabular}{cccc}
\hline $\begin{array}{c}\text { Sl. } \\
\text { No }\end{array}$ & Specimen No & $\begin{array}{c}\text { Ultimate } \\
\text { Load in (N) }\end{array}$ & $\begin{array}{c}\text { Average } \\
\text { Ultimate Load } \\
\text { in (N) }\end{array}$ \\
\hline 1 & TA1 & 4399 & \\
2 & TA2 & 2441 & 3401 \\
3 & TA3 & 3365 & \\
4 & TG1 & 4259 & \\
5 & TG2 & 4034 & 4060 \\
6 & TG3 & 3887 & \\
\hline
\end{tabular}

The Table 1 shows the Ultimate Load results obtained from the universal testing machine. It is observed that for all the three specimens there is a variation on the ultimate load. This is due to the craftsmanship of the riveted joints. Thus the average ultimate load is calculated for the purpose of comparison and it is found that for the Riveted joints without any reinforcement the average ultimate load is $3401 \mathrm{~N}$, and for the riveted joints with GLARE reinforcement the average ultimate load is $4060 \mathrm{~N}$, with the percentage improvement of 19.37.

Table 2. Ultimate Tensile Stress Results

\begin{tabular}{cccc}
\hline $\begin{array}{c}\text { Sl. } \\
\text { No }\end{array}$ & Specimen No & $\begin{array}{c}\text { Ultimate } \\
\text { Stress } \\
\left(\mathbf{N} / \mathbf{m m}^{\mathbf{2}}\right)\end{array}$ & $\begin{array}{c}\text { Average } \\
\text { Ultimate Stress } \\
\left(\mathbf{N} / \mathbf{m m}^{2}\right)\end{array}$ \\
\hline 1 & TA1 & 109 & \\
2 & TA2 & 61 & 84 \\
3 & TA3 & 84 & \\
4 & TG1 & 106 & 100 \\
5 & TG2 & 100 & \\
6 & TG3 & 97 & \\
\hline
\end{tabular}

The Table 2 shows the Ultimate Tensile Stress results obtained from the universal testing machine for the 6 specimens, 3 specimens without the GLARE reinforcement and 3 specimens with the GLARE reinforcement. The average ultimate tensile stress is calculated for the purpose of comparison and it is found that for the Riveted joints without any reinforcement the average ultimate tensile stress is $84 \mathrm{~N} / \mathrm{mm} 2$, and for the riveted joints with GLARE reinforcement the average ultimate tensile stress is $100 \mathrm{~N} / \mathrm{mm} 2$, with the percentage improvement of 19.04 .

\section{CONCLUSION}

The tensile testing of the riveted joints with and without the GLARE reinforced riveted joints was carried out for three specimens each. From the results obtained from the Universal Testing Machine it is observed that when the GLARE material is reinforced in between the plate's of the riveted joints, the Ultimate Load of the riveted joints is improved by $19.37 \%$, and the Ultimate Tensile Stress is improved by $19.04 \%$. This is because the reinforced GLARE composite material absorbs the strain energy responsible for crack propagation along the plates leading to failure of riveted joints.

\section{ACKNOWLEDGMENT}

With great pleasure and deep gratitude, authors wish and express their sincere gratitude to beloved Principal Dr. T. Ramachandran for providing an opportunity and necessary facilities in carrying out this work and express sincere thanks to all the staff members of Aeronautical Engineering whose assistance played a big role in this work and have been of immeasurable value.

\section{REFERENCES}

[1] Suyogkumar W. Balbudhe, and Prof. S. R. Zaveri, Stress Analysis Of Riveted Lap Joint, International Journal of Engineering Research \& Technology (IJERT), Vol. 2 Issue 3, pp.1-4, 2013.

[2] Arumulla. Suresh and Tippa Bhimasankara Rao, Analysis of Rivets Using Finite Element Analysis, International Journal of Computational Engineering Research, Vol. 03, Issue 4, pp. 24-27, 2013.

[3] AdVlot, GLARE -History of the Development of a New Aircraft Material, Kluwer Academic Publishers, ASTM Standard D638-03, D256- 06, D79007, D579- 98 (05), 2001,

[4] P. Kaleeswaran, K. M. Kiran Babu, C. Megala, and B. Sharan Kumar, Fabrication of Fibre Metal Laminate (FML) and Evaluation of Its Mechanical Properties, International Journal of Applied Engineering Research, ISSN 0973-4562 Vol. 9 No.26, pp. 8872-8874, 2014.

[5] Ritchie, R.O., Mechanism of Fatigue Crack Propagation in Ductile and Brittle Solids, International Journal of Fracture, 100, pp. 55-83, 1999.

[6] Kesavamurthy, Y C, Dr. Nanjundaradhya N V, Dr. Ramesh S Sharma, and Dr. R S Kulkarni, Investigation of Tensile Properties of Fibre 
Reinforced Angle Plate Laminated Composites, International Journal of Emerging Technology and Advanced Engineering, Volume 2, Issue 4, pp.700703, April 2012.

[7] Skorupa, M., and Skorupa A., Load transmission and secondary bending in lap joints of aircraft fuselage. Institute of Aviation Scientific Publications, Warsaw, 2010.

[8] K.Madhan Muthu Ganesh, Damage Tolerant Design for an Aero structural Component, Proceedings of Emerging Trends in Mechanical Engineering, SNS College of Technology, Coimbatore, 2010.

\section{ОЈАЧАНОГ СТАКЛЕНИМ ВЛАКНИМА}

\section{Р. Пранеш, М. Хеманатан, К. Бабу, С. Сендхилкумар}

Конструкција сваке летилице обухвата структурне елементе као што су уздужнице и ојачања који су направљени од металних лимова спојених закованим металним преклопним спојевима. Иако постоје различите технике спајања, закивање је ипак најефикаснија техника. Бројни закивци су неопходни да би се направио потпуни спој површинске оплате. Механичко оптерећење узроковано компресијом и декомпресијом у трупу, које се догађа једанпут при сваком лету и оптерећење ваздуха за време лета на режиму крстарења, доводе до концентрације напона у закивцима, што доводи до отказа спојева. Главни циљ овог рада је да се побољша чврстоћа закивака применом металног композита (алуминијума) ојачаног стакленим влакнима као материјала за ојачање између закованих спојева. Извршено је испитивање узорака на затезање са и без ојачања и на основу резултата се закључује да се укупна механичка чврстоћа закивака побољшава захваљујући присуству ојачања између закованих спојева. 